\title{
Then and Now: COVID-19 Pandemic Lockdown Misfire Atmospheric Methane over India
}

\section{Aerosol and Air Quality Research}

Special Issue:

Special Issue on Air Quality in a Changed World: Regional, Ambient, and Indoor Air Concentrations from the COVID to Post-COVID Era (IV)

\section{OPEN ACCESS}

Received: November 30, 2021

Revised: February 9, 2022

Accepted: February 26, 2022

${ }^{*}$ Corresponding Author:

tyagib@nitrkl.ac.in

\section{Publisher:}

Taiwan Association for Aerosol Research

ISSN: $1680-8584$ print

ISSN: 2071-1409 online

Copyright: The Author(s). This is an open access article distributed under the terms of the Creative Commons Attribution License (CC BY 4.0), which permits unrestricted use, distribution, and reproduction in any medium, provided the original author and source are cited.

\section{Manoj Hari ${ }^{\circledR}$, Rajesh Kumar Sahu ${ }^{\circledR}$, MS Shyam Sunder ${ }^{\circledR}$, Bhishma Tyagi ${ }^{*} *$}

Department of Earth and Atmospheric Sciences, National Institute of Technology Rourkela, Odisha 769008, India

\section{ABSTRACT}

COVID-19 lockdown resulted in the revival of the environment due to reduced emissions of various pollutants globally. In particular, aerosols, $\mathrm{NO}_{x}$ and $\mathrm{SO}_{2}$ showed significant reductions at most places. However, the greenhouse gases are not necessarily following this reduction everywhere. In most areas, a decrease in $\mathrm{NO}_{x}$ increases methane $\left(\mathrm{CH}_{4}\right)$ concentration by enhancing the lifetime, but also results in decreased concentrations with reduced emissions. Analyzing the atmospheric $\mathrm{CH}_{4}$ variations during the COVID-19 lockdown over India is crucial as India is one of the regions with high seasonal variability of $\mathrm{CH}_{4}$. The present study has analyzed the tropospheric $\mathrm{CH}_{4}$ trends over India during the pre-monsoon season (March-May) for 2003-2021 using AIRS data. The study analyzed the lockdown variations (24 March-31 May) of tropospheric $\mathrm{CH}_{4}$ over India with the same period of 2019 and 2021 using TROPOMI to find the changes in $\mathrm{CH}_{4}$ concentrations over different regions of India due to lockdown. Our results capture the undeviating north (low)-south (high) gradient in the $\mathrm{CH}_{4}$ concentration with anticipated regional intensifications, likely, in the eastern and western coastal regions, with more comprehensive details than it ever has been presented before.

Keywords: Atmospheric methane, NOx, COVID-19 lockdown, Seasonal variability, TROPOMI

\section{INTRODUCTION}

With a considerable residence time (7.2-10.1 years, with an average value of 9 years) in the troposphere (Morgenstern et al., 2018), Methane $\left(\mathrm{CH}_{4}\right)$ - a potent greenhouse gas (GHG) holds the global warming potential of about 28-36\% for a century (Hogan et al., 1991; Forster et al., 2007). Anthrophonic instigation increased the atmospheric $\mathrm{CH}_{4}$ to $259 \%$ higher than the preindustrial level (Dlugokencky et al., 1994; WMO, 2019). Though the growth rate is slowed down due to strict policies globally (Dlugokencky et al., 1998), the atmospheric concentrations are already too high. Comparatively, $\mathrm{CH}_{4}$ at global scale exhibit huge interannual annual fluctuations by rapid positive instability in $\mathrm{CH}_{4}$ sources every year, which notably cause significant uncertainty in regulating the atmospheric $\mathrm{CH}_{4}$ concentration. Leading which, quantifying the $\mathrm{CH}_{4}$ budget remains highly elusive, and thus, evaluating the variability is consequential for better projection of atmospheric $\mathrm{CH}_{4}$.

As the sources of atmospheric $\mathrm{CH}_{4}$ are both natural and anthropogenic, the global atmospheric $\mathrm{CH}_{4}$ puts India as one of the top contenders for $\mathrm{CH}_{4}$ emissions, including natural wetlands, biomass and biofuel burning, agricultural waste and fossil fuels (Saunois et al., 2020). According to a field campaign in 1991, the Indian paddies $\mathrm{CH}_{4}$ budget average is $4 \mathrm{Tg}_{\text {year }}{ }^{-1}$ (Parashar et al., 1996). The annual values of $\mathrm{CH}_{4}$ emissions from coastal wetlands of southern India ranged from $3.10 \mathrm{mg} \mathrm{m}^{-2} \mathrm{hr}^{-1}$ (Bay of Bengal) to $21.56 \mathrm{mg} \mathrm{m}^{-2} \mathrm{hr}^{-1}$ (Adyar River), apart from the seasonal variations (Purvaja and Ramesh, 2001). Between 2002 and 2003, the estimated average value of $\mathrm{CH}_{4}$ flux from municipal solid waste landfill areas varied from $146-454 \mathrm{mg} \mathrm{m}^{-2} \mathrm{hr}^{-1}$ (Rawat et al., 2008). Guha et al. (2018) utilized in-situ observations from two tropical Indian stations (Sinhagad and Cape Rama) to analyze the seasonal variability of $\mathrm{CH}_{4}$, with minimum values associated with 
southwest monsoon and maximum values over northeast monsoon. Tiwari et al. (2020) also noticed seasonal variability and sub-seasonal variability over these sites using both in-situ and model simulations. Recently, Singh et al. (2021) explored the $\mathrm{CH}_{4}$ variability over India using GOSAT data from 2009-2020 and analyzed the year-wise progression of seasonal and annual $\mathrm{CH}_{4}$. As expected, the $\mathrm{CH}_{4}$ concentrations are increasing over India from 2009-2020, with higher concentrations over parts of central, eastern and southwest regions. For the pre-monsoon season (i.e., MarchMay), the $\mathrm{CH}_{4}$ variability trends show a gradient from north to south (low to high values) over India. The average values showed that the post-monsoon season experienced the highest concentrations, followed by winter, monsoon and pre-monsoon (Singh et al., 2021). However, the study has not accounted for the year 2020 abnormal variations over the country. For feasibility, some of the selective studies with comprehensive summary and characteristics are listed in Table 1.

The unprecedented spread of COrona VIrus Disease-19 (COVID-19) worldwide in early 2020 forced most of the world to go into a state of lockdown (Karatayev et al., 2020), resulting in a shift in modern lifestyle globally, with a negative response to isolation (Thakur and Jain, 2020) and a positive response to the environment (Muhammad et al., 2020). The revive in the environment is more pronounced over the countries like India, where the ambient air pollution was high and shared a significant burden on health (Balakrishnan et al., 2019; Gautam, 2020; McDonald et al., 2020). The Government of India imposed a lockdown from 24 March-31 May 2020 to combat the COVID-19 spread over the country (https://www.mygov.in/covid-19; Bherwani et al., 2020). The global lockdown due to COVID-19 resulted in a significant decrease in aerosols, $\mathrm{NO}_{x}$ and $\mathrm{SO}_{2}$; however, not in the greenhouse gas $\left(\mathrm{CO}_{2}\right.$ and $\left.\mathrm{CH}_{4}\right)$ concentrations. The reasons for no reductions were decreased ocean uptake of $\mathrm{CO}_{2}$ and a likely increase in $\mathrm{CH}_{4}$ lifetime from reduced $\mathrm{NO}_{x}$ emissions. These changes in $\mathrm{CO}_{2}$ and $\mathrm{CH}_{4}$ are further moderated by carbon-cycle feedbacks to $\mathrm{CH}_{4}$ and $\mathrm{CO}_{2}$ along with background pollutant levels and wildfires apart from other factors (Laughner et al., 2021). Stevenson et al. (2021) also supported the increase in $\mathrm{CH}_{4}$ concentration due to reduced $\mathrm{NO}_{\mathrm{x}}$ concentrations globally during the COVID-19 lockdown. However, localized studies across the globe portrayed contradicting results during the lockdown (Rendana et al., 2021; You et al., 2021).

Over the Indian region, the primary focus for analyzing the reduction in atmospheric pollution remains on particulate matter, $\mathrm{NO}_{x}$ and $\mathrm{SO}_{2}$ (e.g., Sahu et al. (2020), Singh et al. (2020), Hari et al. (2021), Singh and Tyagi (2021), and Tyagi et al. (2021)). Limited studies have reported the variations in $\mathrm{CH}_{4}$ during the lockdown period. Notably, Chauhan and Singh (2021) used AIRS satellite data over six megacities of India, and Behera et al. (2021) focused on seven west-east Indian agro-climatic zones by utilizing Sentinel-5P data and highlighted the increased $\mathrm{CH}_{4}$ concentrations. Behera et al. (2021) reported that the seasonal variability of $\mathrm{CH}_{4}$ was linked to crop-residual burning, and the study defined higher $\mathrm{CH}_{4}$ values in 2021. Similarly, Dutta et al. (2021) argued that the increase in $\mathrm{CH}_{4}$ over India agreed with the global rise using Sentinel-5P. However, the data gaps in their visualized analysis do not fully support their conclusion. From a global $\mathrm{CO}_{2}$ and $\mathrm{CH}_{4}$ perspective, no significant variations of $\mathrm{CH}_{4}$ were reported concerning lockdown (Sharma and Verma, 2021), which was supported by Tibrewal and Venkataraman (2021) findings, who summarised insignificant variations in $\mathrm{CH}_{4}$ during COVID-19 lockdowns over India. However, the reported studies over India during the COVID-19 lockdown period did not explicitly explore the lockdown period compared to the previous period/year and afterward concentration. The present study is an attempt to cover this gap by analyzing trends in $\mathrm{CH}_{4}$ concentrations during the pre-monsoon season for 2003-2021 and comparing the total lockdown period (24 March-31 May 2020) with similar periods in the preceding year (2019) and succeeding year (2021). The study aims to understand the spatial variations in $\mathrm{CH}_{4}$ during COVID-19 lockdowns over the whole of India. The study highlights the rectilinear behaviour of $\mathrm{CH}_{4}$ across India and the seasonal trends, which can help to improve the understanding of Indian $\mathrm{CH}_{4}$ concentrations.

\section{DATA AND METHODOLOGY}

The study employs multiple earth observation platforms to analyze the intensity and variability of atmospheric column-averaged dry-air mole fractions of $\mathrm{CH}_{4}\left(\mathrm{XCH}_{4}\right)$ over India, detailed in the following sections. The data were pre-processed and filtered by quality assurance for each time step. 


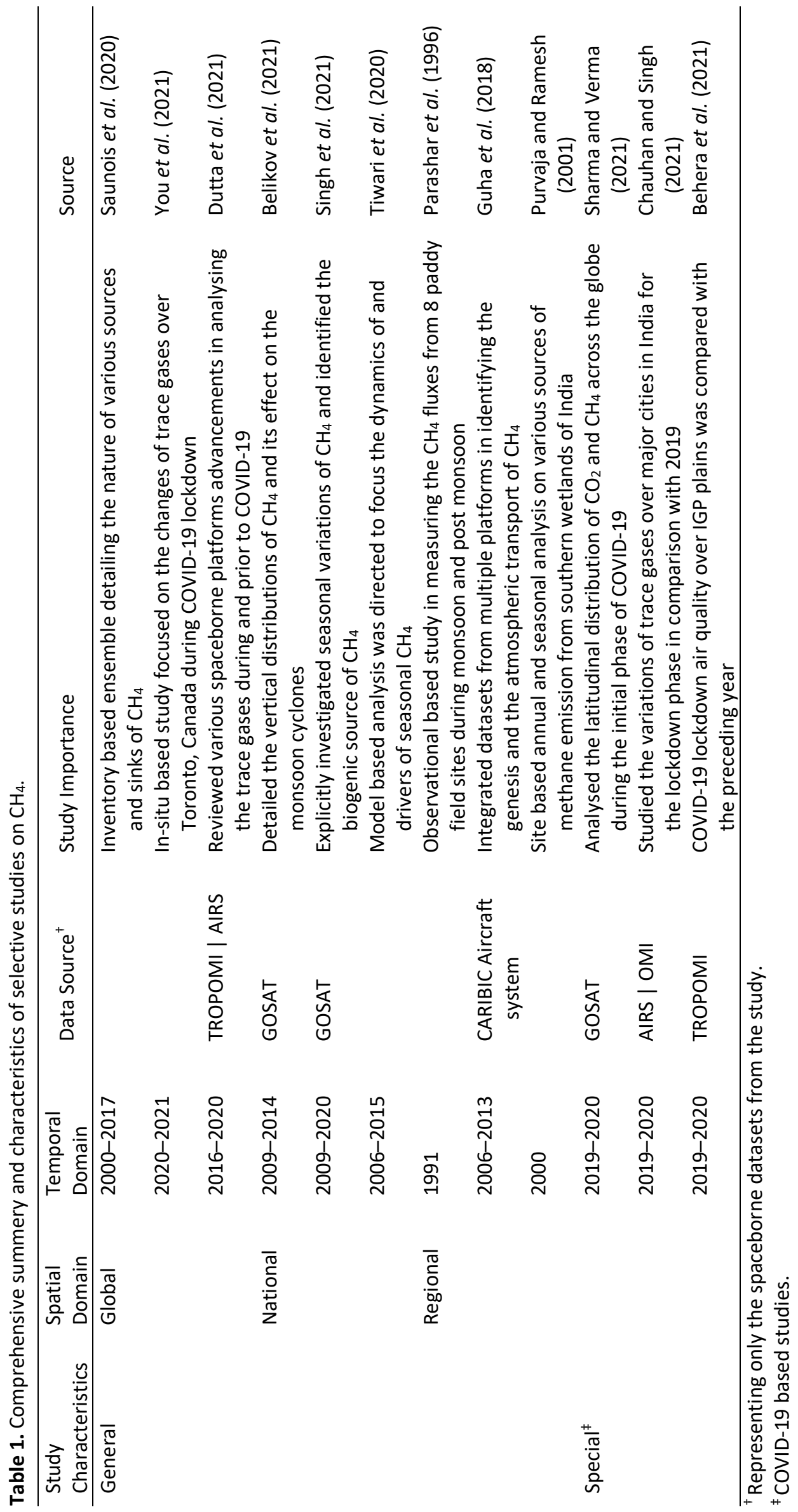




\subsection{Sentinel-5P Data}

TROPOsferic Monitoring Instrument (TROPOMI) of Sentinel 5P platform traces major air pollutants: $\mathrm{CO}, \mathrm{CH}_{4}, \mathrm{HCHO}, \mathrm{O}_{3}, \mathrm{NO}_{2}$ and $\mathrm{SO}_{2}$ at the top of the Atmosphere (TOA) with a higher spatial resolution of $7.5 \mathrm{~km}$ daily (Hari et al., 2021). For this study, level 2 of the $\mathrm{CH}_{4}$, retrieved by the TROPOMI/WFM-DOAS algorithm, which is limited to cloud-free scenes, was selected and analyzed. TROPOMI yields $\mathrm{XCH}_{4}$ from spectral bands $0.76 \mu \mathrm{m}$ (Oxygen-A band) $-1700 \mu \mathrm{m}$ (SWIR band) and are validated ground-based TCCON and by GOSAT satellite (Hasekamp et al., 2021). $\mathrm{XCH}_{4}$ from TROPOMI has retrieved measurements including the Planetary Boundary Layer (PBL), proportionate for studies at higher spatial scales. For better analysis, OFFL products were chosen and filtered by quality assurance. To maintain the scope of the article, the study employed the data retrieved for the period of three years: 2019 (pre-lockdown year), 2020 (lockdown year) and 2021 (post-lockdown year). The errors in data acquisition result in the missing data for the analysis period. Most of the analysis details the variability of $\mathrm{XCH}_{4}$ for the lockdown dates (24 March-31 May), whereas the supplement document expounds the seasonal variations for the aforementioned years.

\subsection{Atmospheric Infrared Sounder (AIRS) Data}

For this current study, the data is taken from the Aqua-AIRS (Atmospheric Infrared Sounder) satellite, which has a spatial resolution of $1^{\circ} \times 1^{\circ}$ and a temporal resolution of $1-2$ times per day. This satellite passes through the equator twice a day, and over India, it passes the orbit in the ascending band at 13:30 LT (Local Time) (daytime) and in the descending band at 1:30 LT (nighttime). To analyze the trend over the Indian subcontinent, we isolated the data for the pre-monsoon period from 2003 to 2021.

\subsection{Trend Analysis}

At the $95 \%$ confidence level $(\rho<0.05)$, the Mann-Kendall test (MKT), a non-parametric statistical test for analyzing patterns in time-series datasets, was applied in the current study (Yue et al., 2002; Asoka et al., 2017; Vissa et al., 2019). The MKT accepted the null hypothesis as the absence of any monotonic pattern in a time series, with pattern values that can be positive or negative. Sen's slope is used to calculate the trends in this trend test (Sen, 1968).

\section{RESULTS AND DISCUSSION}

\subsection{Trend of Tropospheric $\mathrm{CH}_{4}$}

Fig. 1 shows the Mann Kendall trend test for $\mathrm{CH}_{4}$ from 2003 to 2021 for the pre-monsoon season. Panel-a from Fig. 1 shows the trend for ascending band (during daytime 13:30 local time), Panel-b shows the trend for descending band (during night time 1:30 local time) and Panel-c shows the combination of both the bands. We used this bimodal trend combination to differentiate the $\mathrm{CH}_{4}$ concentration (expressed in ppb season ${ }^{-1}$ ) between day and night. From Fig. 1, we observed an overall positive trend across India (ascending (Fig. 1(a)), descending (Fig. 1(b)) and a combination of both (Fig. 1(c)). In the ascending band's trend analysis, a substantially steady trend was observed over the Indo-Gangetic Plain (IGP) extending from west to east. In contrast, a higher positive trend was observed in the western coasts of Gujarat plains. No trend was found in the northernmost part of India in the ascending band. For the descending band, an overall positive trend was observed across India with higher values, especially over the western and northwestern parts of the country. The trend varied from 3.5 to $5 \mathrm{ppb}$ season $^{-1}$, which was the highest compared to other regions of the country. The trend in the northern part of the country was in harmony with the ascending band. In the combinational band, the trend was unequivocally positive over India with no trend over the northernmost part. While comparing the northern and southern parts for all the bands, south India exhibited a lesser positive trend than north India, highlighting its pertaining $\mathrm{CH}_{4}$ concentrations. The $\mathrm{CH}_{4}$ concentration was higher in the descending band, i.e., during the nighttime compared to the ascending band (daytime) across the country. The MKT analysis exhibited unequivocally statistical significance across the country with $\rho<0.05$ for all the bands (Cao et al., 2019). 

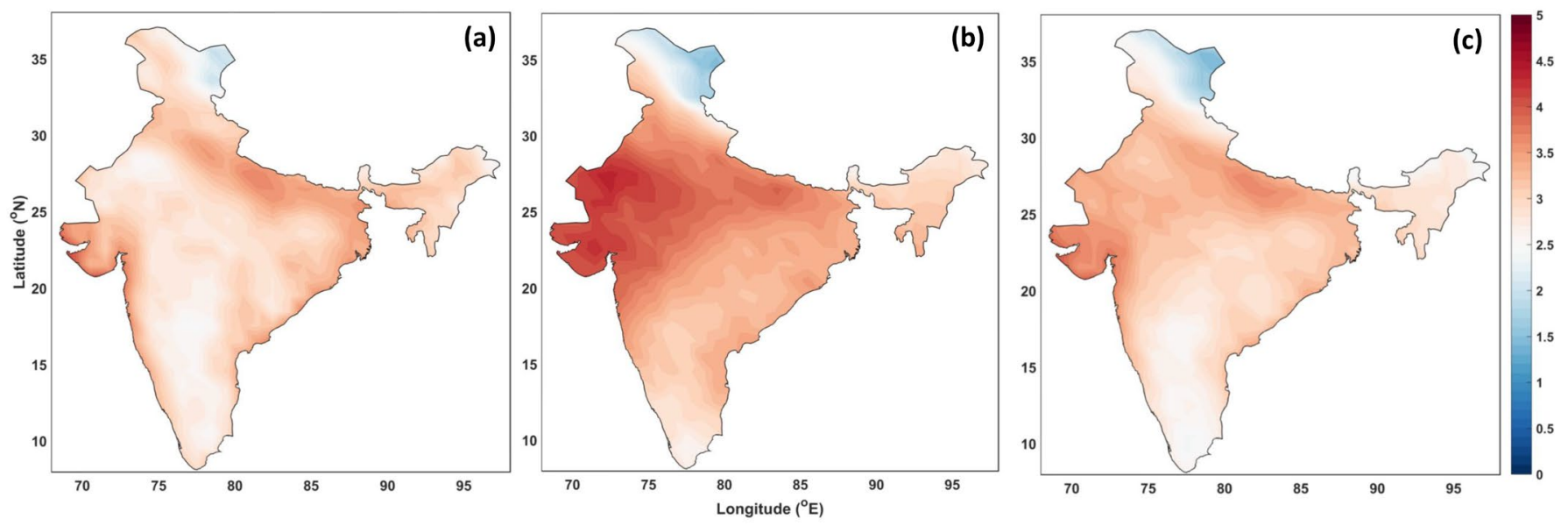

Fig. 1. $\mathrm{XCH}_{4}$ trend isolated for 2003-2021, from AIRS for the pre-monsoon season (MAM) for (a) ascending node (b) descending node and (c) fused, with a significance threshold $\rho<0.05$.

\subsection{Spatial and Seasonal Distribution of $\mathrm{CH}_{4}$ Concentrations over India: Pre-, During- and Post-lockdown}

The $\mathrm{XCH}_{4}$ concentration for India exhibits a substantial variation in the spatial distribution. The northwestern regions of the country observed the persistence of strong $\mathrm{CH}_{4}$ episodes with an average of $1924.48 \pm 42 \mathrm{ppbv}$ (Fig. 2). Conversely, central India holds a lower $\mathrm{XCH}_{4}$ concentration with a mean of $1868.59 \pm 26$ ppbv. India's eastern and western coastal regions share the concentration traits with the central region, which could be inferred to the sea breeze from the Bay of Bengal and Arabian sea, as the vertical air circulations could help in the dispersion of nearsurface $\mathrm{CH}_{4}$ (Belikov et al., 2021). Apart from the natural emissions from the IGP, the south-central region reflects relatively higher variation, an annual mean of $1908.33 \pm 33$ ppbv, indicating the heterogeneity of $\mathrm{XCH}_{4}$ concentrations in urban sprawl. The Sundarbans wetland mainly regulates static high concertation over the northeastern coastal region (West Bengal). They were the highest concentrated $\mathrm{CH}_{4}$ zone by natural source with a mean of $1901.97 \pm 19 \mathrm{ppbv}$, with superimposed $\mathrm{XCH}_{4}$ concentrations by the nearby thermal power plant hub (Hajny et al., 2019), known to be the fugitive $\mathrm{CH}_{4}$ emitters. The most intensive hub in the northeastern region, the Sundarbans wetland and forest vegetation in central India hold a steady trend across seasons. Due to the permanent snow cover, the northernmost and easternmost part of India exhibits less $\mathrm{XCH}_{4}$ concentration.

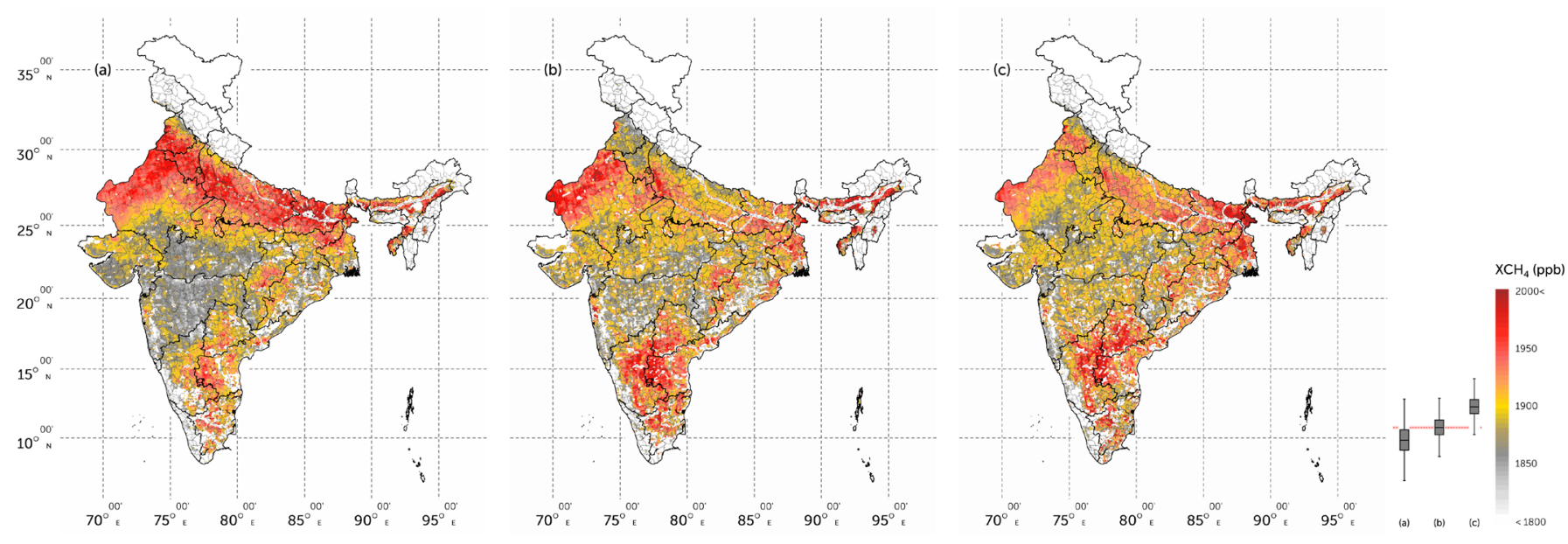

Fig. 2. TROPOMI XCH 4 averaged for the lockdown period (March 24-May 31) for (a) pre-lockdown year 2019, (b) lockdown year 2020 and (c) post-lockdown year 2021. The box plot highlights the variability of $\mathrm{XCH}_{4}$ for the corresponding year, and the red dash with shades signifies the mean $\mathrm{XCH}_{4}$ concentration for India (1883 $\pm 15 \mathrm{ppbv}$ ). Data coverage for the analyzing period accounts for $92.56 \%, 91.17 \%$ and $92.01 \%$, respectively. 
The overall spatial distribution of $\mathrm{XCH}_{4}$ concentrations shows an evident northward propagation with positive amplitude across time with a seasonal shift in the intensity. However, different ecosystems indicate the concentrations at higher significance due to various local drivers such as paddy cultivation, livestock propagation, wetland emissions, thermal power plants, mining.

By decoding the $\mathrm{XCH}_{4}$ concentrations from the TROPOMI platform, the most noticeable seasonal changes were observed for the winter season (DJF) next to monsoon (JJAS), influenced by meteorological factors. However, due to the minimum data coverage in the monsoon period, distinct seasonal variability remains elusive. The amplitude in the monsoon seasonal shifts the $\mathrm{XCH}_{4}$ concentrations from north-west to the IGP belt due to the enhanced Kharif seasonal cropping (especially paddy), which redistributes the $\mathrm{XCH}_{4}$ across the region with almost $50 \%$ variability across the season. Fig. S1 in the supplement document signifies this evident shift of the $\mathrm{XCH}_{4}$ concentrations in the monsoon season. With the monsoon retrieval, the concentrations across the northern regions were suppressed by the shift towards southern and eastern India during post-monsoon. But the winter peak (Fig. S3) corresponds with the dominance of anthropogenic sources from the urban hub, along with a small hike in the concentrations in the northeast is a subset of the spring rice cultivation.

As the present study focuses on the lockdown impact on $\mathrm{XCH}_{4}$ concentrations, we isolated our AIRS climatological trend analysis to the pre-monsoon season (MAM) but not for the TROPOMI platform. From Figs. S1 and S2 in the supplement document, $\mathrm{XCH}_{4}$ concentrations peaked during the monsoon and post-monsoon due to the intensive paddy cultivation of the IGP belt, considered to be the high potential emitter of $\mathrm{XCH}_{4}$. For perpetual cultivation, crop biomass burning practice is maintained across India, further adding the $\mathrm{XCH}_{4}$ concentrations, especially during the postmonsoon season (Fig. S2), particularly in the IGP belt. Due to the seasonal intensive agricultural zone, the peninsular regions hold maximum concentrations of $\mathrm{XCH}_{4}$ for pre-and post-monsoon (Figs. 2 and S2). The southern part of India observed a patch of intense $\mathrm{XCH}_{4}$ during winter (Fig. S3) and pre-monsoon season (Fig. 2), with a peak of $+25 \mathrm{ppb}$ than the relative annual mean (1881.97 \pm 12 ppbv).

India's $\mathrm{XCH}_{4}$ concentrations are naturally dependent (with agriculture), mediated by meteorological factors. However, possible anthropogenic sources contribute to a possible extent during the lockdown measures. Fig. 2 provides an outline of TROPOMI XCH $\mathrm{XV}_{4}$ over India for the lockdown phase (March 24-May 31) of 2020 (Fig. 2(b)), in comparison to the same temporal step in 2019 (Fig. 2(a)) and 2021 (Fig. 2(c)). Comparatively, the $\mathrm{XCH}_{4}$ concentrations over India are lower, with evident prominence in the IGP belt. Although, the concentration in the south-central domain appears to be on the positive shift irrespective of the lockdown. As expected, the $\mathrm{XCH}_{4}$ concentrations during lockdown faced a substantial decline in the agricultural belt and the urban areas. $\mathrm{The}^{\mathrm{XCH}}$ concentrations were not compromised on the northeastern front during the lockdown year (Fig. 2(b)) due to operational thermal power plants. Significantly, a phase shift in the latitudinal trend was observed during the lockdown year (Fig. 2(b)) with pronounced concentrations over southern India. Being $\mathrm{NO}_{x}$ sensitive regions during the pre-monsoon season, the northern parts of India, particularly the IGP plains, are mostly agriculturally non-intensive. However, the regions in the south (e.g., Telangana and Tamil Nadu) are assimilated to the summer cropping. This, in fact, turns out to be an important reason for the substantial $\mathrm{XCH}_{4}$ concentration variability across these regions.

Mean $\mathrm{XCH}_{4}$ concentrations for northern (southern) India was $1925 \pm 24$ (1873 \pm 28 ) ppbv, whereas the anomaly shift during the lockdown was $-29(+21)$ ppbv, respectively. During the lockdown period, the decline in the $\mathrm{XCH}_{4}$ concentrations was considerably more significant than the $\mathrm{XCH}_{4}$ climatology trend (Fig. 1(c)) over the IGP. In contrast, it transcends the climatological trend in the south-central region. Though the climatology over the western front was higher than the threshold ( $1883 \pm 15$ ppbv), observations by TROPOMI declined such a trend, especially for the lockdown year. Most of the pollutants and GHGs reflect higher variability in a fading global trend in 2020 as an effect of the COVID-19 pandemic lockdown. But, in agreement with the worldwide studies (Chauhan and Singh, 2021; Dutta et al., 2021; Rendana et al., 2021; Stevenson et al., 2021), our analysis indicates that $\mathrm{XCH}_{4}$ concentration was progressively increasing with reduced intensity over India, which might be to the reduction in carbon emissions. Before the lockdown face (March 1-March 23), the initial phase of pre-monsoon season, the $\mathrm{XCH}_{4}$ concentrations remain to follow the year 2019 with an increment of +11 ppbv year $^{-1}$, which can be inferred from Fig. S4 
in the supplement document. Being the season for Rabi crops (i.e., wheat, barley), the soil remains aerobic during pre-monsoon, unlike monsoonal season, which favours soil methanogenesis (Dutta et al., 2021).

\title{
4 CONCLUSIONS
}

The enormity of climate change by global warming is daunting. The COVID-19 pandemic lockdown-related fall in the pollutants level is nothing but a mere blip in the long trend, which is not an offset for the changing climate. However, the COVID-19 pandemic reflected the facet of our climate system, which provided us with a platform to understand the changing environment to reach out to a sustained flattening in the climate change curve. To combat the climate crisis, the ability to monitor GHGs across the changing environmental conditions is an essential prerequisite. In light of that, our study underscores the variability and dynamics of $\mathrm{CH}_{4}$ concentrations over India in the recent past, compared to the COVID-19 lockdown period using satellite atmospheric measurements. The results from the present study can be concluded as follows:

- The $\mathrm{XCH}_{4}$ trends are increasing over the Indian region. However, the magnitude of rising trends is higher over the western-northern region (including the IGP) compared to southern India.

- South India showed increased in $\mathrm{XCH}_{4}$ concentrations, whereas the IGP showed a significant decrease. The results show that the $2021 \mathrm{XCH}_{4}$ concentrations over IGP are still less than the values of 2019 , whereas the south Indian region still has higher concentrations.

- The results advocate that India is showing both reductions and enhancements in $\mathrm{XCH}_{4}$ concentrations. The north Indian region shows reduced $\mathrm{XCH}_{4}$ concentrations due to reduced emissions associated with COVID-19 lockdown and subsequent unlock phases. In contrast, south India shows increased $\mathrm{XCH}_{4}$ concentrations because of increased lifetime due to reduced $\mathrm{NO}_{x}$ emissions.

Needless to say, TROPOMI has facilitated the study by offering extended monitoring potential. However, the lack of data coverage in the analyzing period demands a need for an improved measurement network and focus on $\mathrm{CH}_{4}$ emissions over India. Being an agrarian country, with rice as a staple cultivated crop, lack of ground-level information on the seasonal cropland emission, especially for the lockdown period, unskeptically induced uncertainties in the analysis. Holding on to this, local scale studies on cropland $\mathrm{CH}_{4}$ emissions call for further in-depth exploration. Other limitations of the work include analyzing different ecological zones separately for in-depth causeeffect correlation of $\mathrm{XCH}_{4}$ concentrations, which future regional studies can take advantage of.

\section{ADDITIONAL INFORMATION}

\section{Declaration of Competing Interest}

The authors declare that they have no known competing financial interests or personal relationships that could have appeared to influence the work reported in this paper.

\section{Conflict of Interest}

On behalf of all authors, the corresponding author states that there is no conflict of interest.

\author{
Disclaimer \\ Not applicable.
}

\section{ACKNOWLEDGEMENTS}

MH, RKS and SSMS want to acknowledge the National Institute of Technology Rourkela for providing the research fellowship and adequate facilities to conduct this research. The authors want to acknowledge NASA GES DISC for AIRS data and ESA's Copernicus for Sentinel-5P data. The authors acknowledge the constant efforts of all the public and non-public institutions in 
tackling the global COVID-19 pandemic and sharing the relevant information for research. The authors express sincere thanks to two anonymous reviewers for critical evaluation and constructive suggestions to improve the manuscript. We appreciate Prof. Neng-Huei (George) Lin for his kind editorial handling.

\section{SUPPLEMENTARY MATERIAL}

Supplementary material for this article can be found in the online version at https://doi. org/10.4209/aaqr.210354

\section{REFERENCES}

Asoka, A., Gleeson, T., Wada, Y., Mishra, V. (2017). Relative contribution of monsoon precipitation and pumping to changes in groundwater storage in India. Nat. Geosci. 10, 109117. https://doi.org/10.1038/ngeo2869

Balakrishnan, K., Dey, S., Gupta, T., Dhaliwal, R.S., Brauer, M., Cohen, A.J., Stanaway, J.D., Beig, G., Joshi, T.K., Aggarwal, A.N., Sabde, Y., Sadhu, H., Frostad, J., Causey, K., Godwin, W., Shukla, D.K., Kumar, G.A., Varghese, C.M., Muraleedharan, P., Agrawal, A., et al. (2019). The impact of air pollution on deaths, disease burden, and life expectancy across the states of India: The Global Burden of Disease Study 2017. Lancet Planet. Health 3, E26-E39. https://doi.org/ 10.1016/S2542-5196(18)30261-4

Behera, M.D., Mudi, S., Shome, P., Das, P.K., Kumar, S., Joshi, A., Rathore, A., Deep, A., Kumar, A., Sanwariya, C., Kumar, N., Chandrakar, R., Seshadri, S., Mukherjee, S., Bhattaram, S.K., Sirivella, Z. (2021). COVID-19 slowdown induced improvement in air quality in India: Rapid assessment using Sentinel-5P TROPOMI data. Geocarto Int. https://doi.org/10.1080/10106049.2021. 1993351

Belikov, D.A., Saitoh, N., Patra, P.K., Chandra, N. (2021). Gosat $\mathrm{CH}_{4}$ vertical profiles over the indian subcontinent: Effect of a priori and averaging kernels for climate applications. Remote Sens. 13, 1677. https://doi.org/10.3390/rs13091677

Bherwani, H., Nair, M., Musugu, K., Gautam, S., Gupta, A., Kapley, A., Kumar, R. (2020). Valuation of air pollution externalities: Comparative assessment of economic damage and emission reduction under COVID-19 lockdown. Air Qual. Atmos. Health 13, 683-694. https://doi.org/ 10.1007/s11869-020-00845-3

Cao, L., Chen, X., Zhang, C., Kurban, A., Qian, J., Pan, T., Yin, Z., Qin, X., Ochege, F.U., De Maeyer, P. (2019). The global spatiotemporal distribution of the mid-tropospheric $\mathrm{CO}_{2}$ concentration and analysis of the controlling factors. Remote Sens. 11, 94. https://doi.org/10.3390/rs11 010094

Chauhan, A., Singh, R.P. (2021). Effect of lockdown on hcho and trace gases over India during March 2020. Aerosol Air Qual. Res. 21, 200445. https://doi.org/10.4209/aaqr.2020.07.0445

Dlugokencky, E.J., Masarie'T, K.A., Lang, P.M., Tans, P.P. (1998). Continuing decline in the growth rate of the atmospheric methane burden. Nature 393, 447-450. https://doi.org/10.1038/ 30934

Dlugokencky, E.J., Steele, L.P., Lang, P.M., Masarie, K.A. (1994). The growth rate and distribution of atmospheric methane. J. Geophys. Res. 99, 17021-17043. https://doi.org/10.1029/ 94jd01245

Dutta, V., Kumar, S., Dubey, D. (2021). Recent advances in satellite mapping of global air quality: Evidences during COVID-19 pandemic. Environ. Sustainability. 4, 469-487. https://doi.org/ 10.1007/s42398-021-00166-w

Forster, P., Ramaswamy, V., Artaxo, P., Berntsen, T., Betts, R., Fahey, D.W., Haywood, J., Lean, J., Lowe, D.C., Myhre, G., Nganga, J., Prinn, R., Raga, G., Schulz, M., Dorland, R. Van (2007). Changes in Atmospheric Constituents and in Radiative Forcing, in: Solomon, S., Qin, D., Manning, M., Marquis, M., Averyt, K., Tignor, M.M.B., Miller Jr., H.L., Chen, Z. (Eds.), Contribution of Working Group I to the Fourth Assessment Report of the Intergovernmental Panel on Climate Change, Cambridge University Press, United Kingdom and New York, p. 106. https://www.ipcc.ch/site/assets/uploads/2018/02/ar4-wg1-chapter2-1.pdf 
Gautam, S. (2020). The influence of COVID-19 on air quality in India: A boon or inutile. Bull. Environ. Contam. Toxicol. 104, 724-726. https://doi.org/10.1007/s00128-020-02877-y

Guha, T., Tiwari, Y.K., Valsala, V., Lin, X., Ramonet, M., Mahajan, A., Datye, A., Kumar, K.R. (2018). What controls the atmospheric methane seasonal variability over India? Atmos. Environ. 175, 83-91. https://doi.org/10.1016/j.atmosenv.2017.11.042

Hajny, K.D., Salmon, O.E., Rudek, J., Lyon, D.R., Stuff, A.A., Stirm, B.H., Kaeser, R., Floerchinger, C.R., Conley, S., Smith, M.L., Shepson, P.B. (2019). Observations of methane emissions from natural gas-fired power plants. Environ. Sci. Technol. 53, 8976-8984. https://doi.org/10.1021/ acs.est.9b01875

Hari, M., Sahu, R.K., Tyagi, B., Kaushik, R. (2021). Reviewing the crop residual burning and aerosol variations during the COVID-19 pandemic hit year 2020 over North India. Pollutants 1, 127140. https://doi.org/10.3390/pollutants1030011

Hasekamp, O., Lorente, A., Hu, H., Butz, A., Brugh, J. de, Landgraf, J. (2021). Algorithm Theoretical Baseline Document for Sentinel-5 Precursor Methane Retrieval. Germany. p. 63. https://sentinel.esa.int/documents/247904/2476257/Sentinel-5P-TROPOMI-ATBD-Methaneretrieval

Hogan, K.B., Hoffman, J.S., Thompson, A.M. (1991). Methane on the greenhouse agenda. Nature 354, 181-182. https://doi.org/10.1038/354181a0

Karatayev, V.A., Anand, M., Bauch, C.T. (2020). Local lockdowns outperform global lockdown on the far side of the COVID-19 epidemic curve. Proc. Natl. Acad. Sci. U.S.A. 117, 24575-24580. https://doi.org/10.1073/pnas.2014385117

Laughner, J.L., Neu, J.L., Schimel, D., Wennberg, P.O., Barsanti, K., Bowman, K.W., Chatterjee, A., Croes, B.E., Fitzmaurice, H.L., Henze, D.K., Kim, J., Kort, E.A., Liu, Z., Miyazaki, K., Turner, A.J., Anenberg, S., Avise, J., Cao, H., Crisp, D., de Gouw, J., et al. (2021). Societal shifts due to COVID19 reveal large-scale complexities and feedbacks between atmospheric chemistry and climate change. Proc. Natl. Acad. Sci. U.S.A. 118, e2109481118. https://doi.org/10.1073/pnas. 2109481118

McDonald, A.J., Balwinder-Singh, Jat, M.L., Craufurd, P., Hellin, J., Hung, N. V., Keil, A., Kishore, A., Kumar, V., McCarty, J.L., Pearson, P., Samaddar, A., Shyamsundar, P., Shirsath, P.B., Sidhu, H.S., Singh, A.K., Singh, S., Srivastava, A.K., Urban, E., Malik, R.K., et al. (2020). Indian agriculture, air pollution, and public health in the age of COVID. 135, 105064. World Dev. https://doi.org/10.1016/j.worlddev.2020.105064

Morgenstern, O., Stone, K.A., Schofield, R., Akiyoshi, H., Yamashita, Y., Kinnison, D.E., Garcia, R.R., Sudo, K., Plummer, D.A., Scinocca, J., Oman, L.D., Manyin, M.E., Zeng, G., Rozanov, E., Stenke, A., Revell, L.E., Pitari, G., Mancini, E., DI Genova, G., Visioni, D., et al. (2018). Ozone sensitivity to varying greenhouse gases and ozone-depleting substances in CCMI-1 simulations. Atmos. Chem. Phys. 18, 1091-1114. https://doi.org/10.5194/acp-18-1091-2018

Muhammad, S., Long, X., Salman, M. (2020). COVID-19 pandemic and environmental pollution: A blessing in disguise? Sci. Total Environ. 728, 138820. https://doi.org/10.1016/j.scitotenv. 2020.138820

Parashar, D.C., Mitra, A.P., Gupta, P.K., Rai, J., Sharma, R.C., Singh, N., Koul, S., Ray, H.S., Das, S.N., Parida, K.M., Rao, S.B., Kanungo, S.P., Ramasami, T., Nair, B.U., Swamy, M., Singh, G., Gupta, S.K., Singh, A.R., Saikia, B.K., Barua, A.K.S., et al. (1996). Methane budget from paddy fields in India. Chemosphere 33, 737-757. https://doi.org/10.1016/0045-6535(96)00223-8

Purvaja, R., Ramesh, R. (2001). Natural and anthropogenic methane emission from coastal wetlands of South India. Environ. Manage. 27, 547-557. https://doi.org/10.1007/s00267 0010169

Rawat, M., Singh, U.K., Mishra, A.K., Subramanian, V. (2008). Methane emission and heavy metals quantification from selected landfill areas in India. Environ. Monit. Assess. 137, 67-74. https://doi.org/10.1007/s10661-007-9729-8

Rendana, M., Idris, W.M.R., Rahim, S.A. (2021). Atmospheric methane condition over the South Sumatera peatland during the COVID-19 pandemic. Aerosol Air Qual. Res. 21, 210072. https://doi.org/10.4209/AAQR.210072

Sahu, S.K., Tyagi, B., Beig, G., Mangaraj, P., Pradhan, C., Khuntia, S., Singh, V. (2020). Significant change in air quality parameters during the year 2020 over 1st smart city of India: Bhubaneswar. SN Appl. Sci. 2, 1990. https://doi.org/10.1007/s42452-020-03831-7 
Saunois, M., Stavert, A.R., Poulter, B., Bousquet, P., Canadell, J.G., Jackson, R.B., Raymond, P.A., Dlugokencky, E.J., Houweling, S., Patra, P.K., Ciais, P., Arora, V.K., Bastviken, D., Bergamaschi, P., Blake, D.R., Brailsford, G., Bruhwiler, L., Carlson, K.M., Carrol, M., Castaldi, S., et al. (2020). The global methane budget 2000-2017. Earth Syst. Sci. Data 12, 1561-1623. https://doi.org/ 10.5194/essd-12-1561-2020

Sen, P.K. (1968). Estimates of the regression coefficient based on Kendall's Tau. J. Am. Stat. Assoc. 63, 1379-1389. https://doi.org/10.1080/01621459.1968.10480934

Sharma, L.K., Verma, R.K. (2021). Latitudinal fluctuation in global concentration of $\mathrm{CO}_{2}$ and $\mathrm{CH}_{4}$ from shortwave infrared spectral observation by GOSAT during COVID-19. Int. J. Digit. Earth. 14, 882-1896. https://doi.org/10.1080/17538947.2021.1980126

Singh, A., Kuttippurath, J., Abbhishek, K., Mallick, N., Raj, S., Chander, G., Dixit, S. (2021). Biogenic link to the recent increase in atmospheric methane over India. J. Environ. Manage. 289, 112526. https://doi.org/10.1016/j.jenvman.2021.112526

Singh, J., Tyagi, B. (2021). Transformation of air quality over a coastal tropical station chennai during COVID-19 lockdown in India. Aerosol Air Qual. Res. 21, 200490. https://doi.org/ 10.4209/aaqr.200490

Singh, V., Singh, S., Biswal, A., Kesarkar, A.P., Mor, S., Ravindra, K. (2020). Diurnal and temporal changes in air pollution during COVID-19 strict lockdown over different regions of India. 266, 115368. Environ. Pollut. https://doi.org/10.1016/j.envpol.2020.115368

Stevenson, D., Derwent, R., Wild, O., Collins, W. (2021). COVID-19 lockdown NOx emission reductions can explain most of the coincident increase in global atmospheric methane. Atmos. Chem. Phys. [preprint] https://doi.org/10.5194/acp-2021-604

Thakur, V., Jain, A. (2020). COVID 2019-suicides: A global psychological pandemic. Brain Behav. Immun. 88, 952-95. https://doi.org/10.1016/j.bbi.2020.04.062

Tibrewal, K., Venkataraman, C. (2021). COVID-19 lockdown closures of emissions sources in India: Lessons for air quality and climate policy. J. Environ. Manage. 302, 114079. https://doi.org/10. 1016/j.jenvman.2021.114079

Tiwari, Y.K., Guha, T., Valsala, V., Lopez, A.S., Cuevas, C., Fernandez, R.P., Mahajan, A.S. (2020). Understanding atmospheric methane sub-seasonal variability over India. Atmos. Environ. 223, 117206. https://doi.org/10.1016/j.atmosenv.2019.117206

Tyagi, B., Choudhury, G., Vissa, N.K., Singh, J., Tesche, M. (2021). Changing air pollution scenario during COVID-19: Redefining the hotspot regions over India. Environ. Pollut. 271, 116354. https://doi.org/10.1016/j.envpol.2020.116354

Vissa, N.K., Anandh, P.C., Behera, M.M., Mishra, S. (2019). ENSO-induced groundwater changes in India derived from GRACE and GLDAS. J. Earth Syst. Sci. 128, 115. https://doi.org/10.1007/ s12040-019-1148-z

World Meteorological Organization (WMO) (2019). World Meteorological Organization (WMO) Greenhouse Gas Bulletin: Greenhouse gas concentrations in atmosphere reach yet another high.WMO. 8. https://library.wmo.int/doc_num.php?explnum_id=10100

You, Y., Byrne, B., Colebatch, O., Mittermeier, R.L., Vogel, F., Strong, K. (2021). Quantifying the impact of the COVID-19 pandemic restrictions on $\mathrm{CO}, \mathrm{CO}_{2}$, and $\mathrm{CH}_{4}$ in downtown toronto using open-path fourier transform spectroscopy. Atmosphere 12, 848. https://doi.org/10.3390/ atmos 12070848

Yue, S., Pilon, P., Cavadias, G. (2002). Power of the Mann-Kendall and Spearman's rho tests for detecting monotonic trends in hydrological series. J. Hydrol. 259, 254-271. https://doi.org/10. 1016/S0022-1694(01)00594-7 